\title{
Increase in Plasma Luteinizing Hormone and Estradiol-17 $\beta$ Concentrations following an injection of Luteinizing Hormone-Releasing Hormone in Incubating and Brooding Gifujidori Hens
}

\author{
Takehito Kuwayama ${ }^{1)}$, Kiyoshi Shimada ${ }^{2)}$, Masaru Wada ${ }^{3)}$ \\ and Katuhide TANAKA ${ }^{1)}$ \\ ${ }^{1)}$ Department of Zootechnical Science, Tokyo University of Agriculture, \\ Setagaya-ku, Tokyo 156 \\ ${ }^{2)}$ Department of Biological Resources and Environmental Science, Nagoya University, \\ Chikusa-ku, Nagoya 464-01 \\ ${ }^{3)}$ Faculty of General Education, Tokyo Medical and Dental University, \\ Kounodai, Ichikawa-shi 272
}

\begin{abstract}
Chicken luteinizing hormone-releasing hormone- I (cLHRH- I) was injected intravenously into incubating and brooding Gifujidori hens, and the plasma concentrations of luteinizing hormone $(\mathrm{LH})$ and estradiol-17 $\beta \quad\left(\mathrm{E}_{2}\right)$ were measured by a radioimmunoassay. The LH concentration increased within 15 min after the injection, and the $\mathrm{E}_{2}$ concentration increased within $60 \mathrm{~min}$. The results suggest that the pituitary of incubating and brooding hens is capable to respond to CLHRH-I and the ovary is also capable to respond to LH released by cLHRH- I .
\end{abstract}

(Jpn. Poult. Sci., 34 : 404-409, 1997)

Key words : LH, estradiol-17 $\beta$, LHRH, incubating hen, brooding hen

\section{Introduction}

Hens of some breeds of the chicken such as Japanese native breeds (Gifujidori, Bantam, etc.) incubate eggs for 21 days and subsequently brood chicks for about two to three months following the lay of eggs successively for a certain period of days. During the incubating and the brooding period, the secretion of luteinizing hormone (LH) (Sharp et al., 1979, 1988 ; KuwAyAma et al., 1992 ; KANSAKU et al., 1994) from the pituitary and estradiol-17 $\beta\left(\mathrm{E}_{2}\right)$ (ZADWORNY et al., 1988 ; KUWAYAMA et al., 1992) from the ovary is at a lower level. Whether the lower level of $\mathrm{LH}$ and $\mathrm{E}_{2}$ is due to a decreased responsiveness of the pituitary and the ovary to their stimulatory factors is obscure. The present experiments were performed to elucidate whether the pituitary of incubating and brooding Gifujidori hens is capable to release $\mathrm{LH}$ in response to chicken luteinizing hormone-releasing hormone-I (cLHRH-I) and whether the ovary is capable to secrete $\mathrm{E}_{2}$ in response to $\mathrm{LH}$ released by the cLHRH-I. 


\section{Materials and Methods}

Gifujidori hens ( 0.8 to $1.0 \mathrm{~kg}$ body wt ; 12 months of age) were kept in individual floor pens (4 birds each in a room of $57 \mathrm{~cm} \mathrm{~W}, 57 \mathrm{~cm} \mathrm{D}$, and $57 \mathrm{~cm} \mathrm{H}$ ) in a temperature controlled house $\left(20 \pm 2^{\circ} \mathrm{C}\right)$. In each room of the house, one nest box $(41 \mathrm{~cm} \mathrm{~W}, 21 \mathrm{~cm} \mathrm{D}$, and $41 \mathrm{~cm} \mathrm{H}$ ) with a sensor of recorder for incubation behavior was placed. Feed and water were provided ad libitum consumption under $14 \mathrm{~h}$ (05:00 to $19: 00)$ light daily. The hens which had continued to incubate eggs for one week after the onset of incubation behavior (sit on egg for more than $23 \mathrm{~h}$ of a $24 \mathrm{~h}$ day) and those continued to brood chicks for one week after hatch were used for experiments.

cLHRH-I (Gln ${ }^{8}-$ LHRH ; Sigma Chem. Co., St. Louis, MO, USA) was dissolved in $0.9 \% \mathrm{NaCl}$ solution and injected intravenously into the incubating and the brooding hens in a dose of $20 \mu \mathrm{g}$ per bird. The volume of injection was $0.5 \mathrm{ml}$. Control hens received an injection of the saline solution. Blood $(1.0 \mathrm{ml})$ was collected from a wing vein using a heparinized syringe immediately before the injection ( " 0 " min.) and at 15 , 30,60 and $120 \mathrm{~min}$ after the injection successively from same hens, and the plasma was obtained and stored at $-20^{\circ} \mathrm{C}$. Within one month, the plasma was assayed for $\mathrm{LH}$ using a homologous radioimmunoassay (RIA) (HATTORI and WAKABAYASHI, 1979), and also for $\mathrm{E}_{2}$ using a routine RIA (KoNo et al., 1981). The intra-assay coefficient of variation $(\mathrm{CV})$ was $7.0 \%(\mathrm{LH})$ and $7.3 \%\left(\mathrm{E}_{2}\right)$, respectively. The inter-assay $\mathrm{CV}$ was less than $8.0 \%$ in both assays.

\section{Results and Discussion}

In both incubating and brooding hens, an increase in the plasma concentration of LH was found at $15 \mathrm{~min}$ after the injection of cLHRH-I (Fig.1). In control (saline injected) hens, no appreciable change was observed up to $120 \mathrm{~min}$. The rate of increase from the level at "0" min. (immediately before injection) was greater in the incubating hens (approximately 6 -fold increase) than in the brooding hens (approximately 4 -fold increase). The greater responsiveness of the pituitary to cLHRH-I for the release of $\mathrm{LH}$ in the incubating hens than in the brooding hens is assumed to be due to a difference in the period of deficiency of an ovarian steroid hormone which stimulates the production of LH in the pituitary cells (KAWASHIMA et al., 1982). This assumption is based on the fact that the time of sampling the plasma from the brooding hens was 3 weeks later from the time of the sampling from the incubating hens and the ovarian steroid hormone secretion is known to be at a low level throughout the incubating and brooding periods (SHARP et al., 1979 ; ZADWORNY et al., 1988 ; KUWAYAMA et al., 1992). SHARP and LEA (1981) reported on Bantam hens that the responsiveness of the pituitary to CLHRH-I for the release of LH was greater in the brooding hens at 3949 days after hatching than in the incubating hens on 5-20 days of incubation. It is assumed that the pituitary responsiveness to $\mathrm{CLHRH}-\mathrm{I}$ may increase at a later stage of the brooding period. At any rate, the increase in the plasma LH concentration in response to CLHRH-I may imply that the pituitary of incubating and brooding Gifujidori hens is capable to release LH if a certain stimulation is provided. 

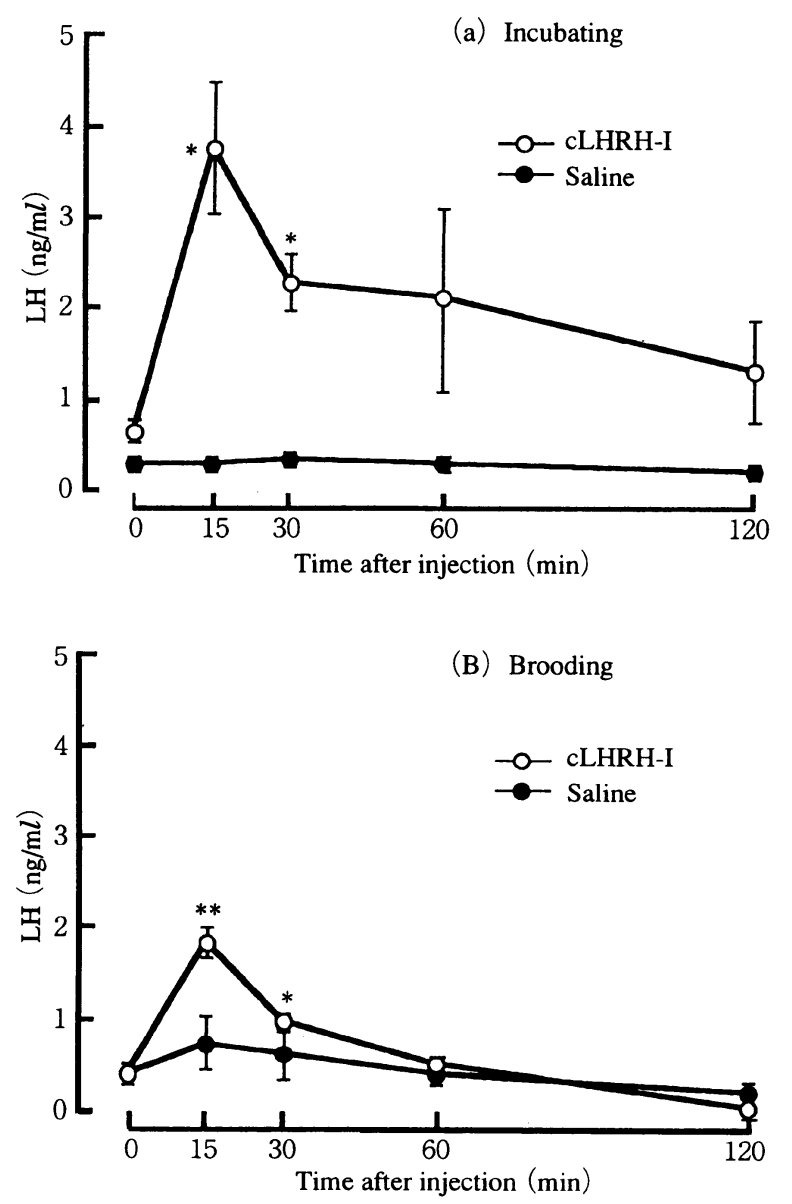

Fig. 1. The plasma concentration of Luteinizing Hormone (LH) in (a) incubating and (b) brooding Gifujidori hens after i.v. injection of $20 \mu \mathrm{g}$ of chicken luteinizing hormonereleasing hormone- I (cLHRH- I) (O) or $0.5 \mathrm{ml}$ of saline solution (O).

The vertical bars represent SEM of 4 birds. Asterisks indicate significant difference $\left({ }^{*} \mathrm{P}<0.05,{ }^{* *} \mathrm{P}<0.01\right)$ from the value at " 0 " min. (immediately before injection).

The plasma $\mathrm{E}_{2}$ concentration was increased following the injection of cLHRH-I and reached a peak at $60 \mathrm{~min}$ after the injection in both incubating and brooding hens (Fig.2). In control hens, no appreciable change was observed up to $120 \mathrm{~min}$. The increase may be due to an indirect effect of cLHRH-I via the pituitary LH release, because the secretion of $\mathrm{E}_{2}$ is stimulated by LH (CAMPER and BURK, 1977 ; ZADWORNy et al., 1989), and because no evidence for the direct action of cLHRH on the ovary of hens has been reported thus far.

The results of the present study suggest that the pituitary of incubating and brooding Gifujidori hens is capable to respond to cLHRH-I and that the ovary is also capable to respond to LH released by the effect of cLHRH-I. The reported low level of 

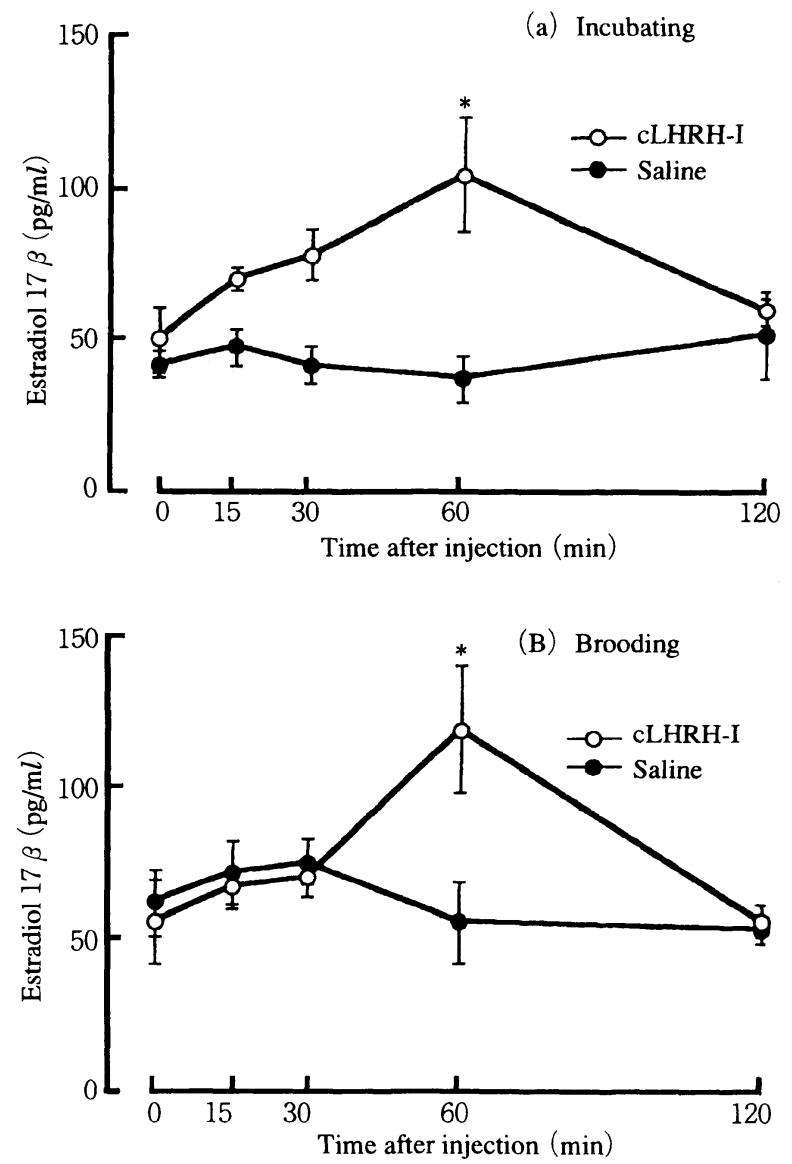

Fig. 2. The plasma concentration of estradiol-17 $\beta$ in (a) incubating and (b) brooding Gifujidori hens after i.v. injection of $20 \mu \mathrm{g}$ of chicken luteinizing hormonereleasing hormone- I (cLHRH- I) $(O)$ or $0.5 \mathrm{~m} l$ of saline solution (O).

The vertical bars represent SEM of 4 birds. Asterisks indicate significant difference $\left({ }^{*} \mathrm{P}<0.05\right)$ from the value at "0" min. (immediately before injection).

plasma $\mathrm{LH}$ and $\mathrm{E}_{2}$ during the incubating and the brooding period (Kuwayama et al., 1992) may not be due to the inability of the pituitary to secrete LH and of the ovary to secrete $\mathrm{E}_{2}$ but to the deficiency of stimulation of the pituitary and the ovary.

\section{Acknowledgments}

This study was supported by Grant-in-Aid for Incentive Research (A) from Ministry of Education, Science and Culture (No. 06856034) and for Joint Research of Monbusho International Scientific Research Program (No. 07044190 to K.S.). This work was reported on XX World's Poultry Congress (New Delhi, India, September 1996) with the aid of the Travel Grant of Japan Poultry Science Association. 


\section{References}

CAMPER, P.M. and W.H. BURK, (1977) The effects of prolactin on the gonadotropin induced rise in serum estradiol and progesterone of the laying turkey. General and Comparative Endocrinology, $32: 72-77$.

HATTORI, M. and K. WAKABAYASH (1979) Isoelectric focusing and gel filtration studies on the heterogeneity of avian pituitary luteinizing hormone. General and Comparative Endocrinology, 39 : 215-221.

Kansaku, N., K. Shimada, O. Terada and N. Saito (1994) Prolactin, growth hormone, and luteinizing hormone $\beta$ subunit gene expression in the cephalic and caudal lobes of anterior pituitary gland during embryogenesis and different reproductive stage in the chicken. General and Comparative Endocrinology, $96: 197-205$

Kawashima, M., M. Kamiyoshi, K. Tanaka, M. Hattori and K. Wakabayashi (1982) Effects of progesterone on pituitary cells of the hen (Gallus domesticus) during the ovulatory cycle for production and release of LH and FSH. General and Comparative Endocrinology, $48: 362-371$.

Kono, T., H. IтOH and K. ICHINOE (1981) Measurement of sex steroid hormones in blood plasma and follicle of chickens by radioimmunoassay. Journal of Agriculture Science, Tokyo Nogyo Daigaku, Commemoration Number of 90th Anniversary of Foundation : 257-265.

Kuwayama, T., K. Shimada, N. Saito, T. Ohkubo, K. Sato, M. Wada and K. Ichinoe, (1992) Effects of removal of chicks from hens on concentrations of prolactin, luteinizing hormone and estradiol in plasma of brooding Gifujidori hens. Journal of Reproduction and Fertility. 95 : 617622.

Sharp, P.J., C.G. Scanes, J.B. Williams, S. Harvey and A. ChadWick, (1979) Variations in concentrations of prolactin, luteinizing hormone, growth hormone and progesterone in the plasma of broody bantams (Gallus domesticus). Journal of Endocrinology, 80 : 51-57.

SHARP, P.J. and R.W. LEA, (1981) The response of the pituitary gland luteinizing hormone-releasing hormone in broody bantams. General and Comparative Endocrinology, $45: 131-133$.

Sharp, P.J., M.C. Macnamee, R.J. Sterling, R.W. Lea and H.C. Pedersen, (1988) Relationships between prolactin, LH and broody behaviour in bantam hens. Journal of Endocrinology, 118 : $279-286$.

Zadworny, D., K. Shimada, H. Ishida C. Sumi and K. Sato. (1988) Changes in plasma levels of prolactin and estradiol, nutrient intake, and time spent nesting during the incubation phase of broodiness in the chabo hen (Japanese bantam). General and Comparative Endocrinology, $74: 406-412$.

ZADWORNY, D., K. Shimada, H. IshidA and K. SAto. (1989) Gonadotropinstimulated estradiol production in small ovarian follicles of the hen is suppressed by physiological concentrations of prolactin in vitro. General and Comparative Endocrinology, $74: 468-473$. 


\title{
抱卵および育雛中の岐阜地鶏母鷄における黄体形成ホルモン 放出ホルモン投与後の血漿黄体形成ホルモンおよび エストラジオール濃度の増加
}

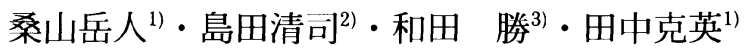 \\ 1) 東京農業大学畜産学科, 東京都世田谷区 156 \\ 2) 名古屋大学資源生物環境学科, 名古屋市千種区 464-01 \\ 3) 東京医科柬科大学教養部, 市川市国府台 272
}

抱卵中および育踓中の岐阜地鶏母鶏の静脈内に二ワト リ黄体形成ホルモン放出ホルモン (cLHRH-I) を投与 し，血漿黄体形成ホルモン（LH）とエストラジオール

$\left(\mathrm{E}_{2}\right)$ 濃度をラジオイムノアッセイにより測定した。LH 濃度は cLHRH- I の投与 15 分以内に上昇し， $\mathrm{E}_{2}$ 濃度は 60 分以内に上昇することが認められ, 抱卵中および育雊
中の岐阜地鵎母鵎の脳下垂体は cLHRH- I に反応し得 ること,また卵巣も CLHRH-Iにより放出された LHに 反応し得ることが示唆された。

(家禽会誌, 34 : 404-409, 1997) キーワード：黄体形成ホルモン, エストラジオール, 黄 体形成ホルモン放出ホルモン, 抱卵, 育雅 